\title{
Environmental Communication, Local Wisdom, and Mitigation of Sampang Flood
}

\author{
Nikmah Suryandari ${ }^{1, a)}$ Qoniah Nur Wijayani ${ }^{2)}$ \\ ${ }^{1}$ Communication Department, Universitas Trunojoyo Madura, Indonesia \\ a) author correspondence: nikmahsuryandari@ trunojoyo.ac.id \\ ${ }^{2}$ Communication Department, Universitas Trunojoyo Madura, Indonesia
}

DOI: https://doi.org/10.18196/jkm.131052

Article Info

Article history:

Received 23 Dec 2020

Revised 27 Mar 2021

Accepted 16 Apr 2021

\section{ABSTRACT}

The people in Sampang Madura are accustomed to flood disasters so routinely that the people had become accustomed to and fully understood the character of the floods. This study aimed to identify the local wisdom of the Madurese community in dealing with, mitigating, and adapting to disasters, especially floods. The research was conducted in three stages: preparation, observation, indepth interviews, and data analysis. The preparation stage was carried out by collecting secondary data about Sampang geography, the disaster histories, and people tradition and custom. In the second phase, in-depth interviews were carried out with the Sampang community and BPBD about how people deal with and adapt to disasters. The third stage was data analysis. The result showed that the people of Sampang had strong belief in their ancestral heritage, that everything comes from God, so they have to face it. People carried out disaster mitigation and adaptation by checking for early signs of disaster and following the advice. Besides, they were always connected with their relatives in other areas who gave early indications of flooding. Moreover, they built houses adaptive to flood. The people of Sampang can face, mitigate, and adapt to natural disasters in their area with confidence, knowledge, and following the advice.

Keywords: Disaster mitigation; Madura local wisdom; Sampang flood

\section{ABSTRAK}

Masyarakat di Sampang Madura telah terbiasa dengan bencana banjir yang rutin melanda daerah mereka. menjadikan masyarakat sangat memahami karakter bencana banjir di wilayah mereka. Penelitian ini bertujuan mengidentifikasi kearifan lokal masyrakat Madura dalam menghadapi, melakukan mitigasi, dan beradaptasi pada bencana, khususnya bencana banjir. Penelitian dilakukan dengan tiga tahapan, yaitu persiapan, observasi dan wawancara mendalam, serta analisa data. Tahap persiapan, dilakukan dengan mengumpulkan data sekunder tentang letak geografis Sampang, sejarah kebencanaan, kebiasaan dan tradisi masyrakat. Tahap kedua dilakukan wawancara mendalam dengan masyarakat Sampang, BPBD mengenai bagaimana masyarakat menghadapi bencana, adaptasi terhadap bencana. Tahap ketiga adalah analisa data, yang menunjukkan bahwa masyarakat Sampang Madura memiliki keyakinan kuat warisan nenek moyang, bahwa segala sesuatu berasal dari Tuhan, sehingga mereka harus menghadapinya. Mereka juga melakukan mitigasi dan adaptasi bencana dengan lebih dini memeriksa tanda-tanda bencana dan mengikuti saran yang diberikan, selain itu mereka juga selalu terhubung dengan kerabat mereka yang berada di wilayah lain yang memberikan indikasi awal terjadinya banjir. Mereka membangun rumah dengan struktur adaptif terhadap bencana banjir. Masyarakat Sampang mampu menghadapi, memitigasi, dan beradaptasi dengan bencana alam di daerahnya dengan keyakinan, pengetahuan, serta mengikuti nasehat yang diberikan.

Keywords: Banjir Sampang; kearifan lokal Madura; mitigasi bencana 


\section{INTRODUCTION}

The Indonesian region has been recognized as a region with distinctive character and uniqueness in the world. Indonesia, which has more than 17,000 islands, has a coastline of more than $80,000 \mathrm{~km}$. This condition makes the country recognized as one of the countries with the most islands and the longest coastline in the world. When viewed from biological diversity, Indonesia is in the third position after Brazil and Colombia. Meanwhile, when viewed from the aspect of volcanology, Indonesia is the location of the most active volcanoes globally and is located in the area where the tectonic plates of the world meet. This situation makes Indonesia prone to volcanic eruptions, tsunamis, and earthquakes. Indeed, the Indonesian archipelago is the area that is passed through by the fire belt or better known as the ring of fire (Suhardjo, 2015).

With this predicate, Indonesia in the last ten years experienced various disasters such as the 2004 Aceh tsunami, the 2006 Yogyakarta earthquake, the 2010 landslide disaster in Wassior, West Papua, and the eruption of Mount Merapi in Yogyakarta, which resulted in hundreds of casualties and losses of trillions of rupiah material. This predicate is emphasized by the condition of the eruption of Mount Merapi that has never subsided (Suhardjo, 2015).

According to Tempo's records, apart from the disaster-hit areas above, other areas in Indonesia are also disaster-potential areas, including Madura. Based on information from the Meteorology, Climatology and Geophysics Agency (BMKG), earthquakes' potential not only occurs in the Madura region but also in most parts of Indonesia. This condition is due to Indonesia's position in the Pacific Ring of Fire which was formed due to active tectonic plate motion (Tempo, 2018). According to BMKG information, the Pacific Ring of Fire is a horseshoe-shaped region with the most active earthquake belt zone in the world. Apart from Indonesia, several countries are also included in this zone, including Japan, Taiwan, and New Zealand (Kompas, 2018). Based on this condition, the government, through the Meteorology, Climatology and Geophysics Agency (BMKG), hopes that the community and other stakeholders will be more proactive in preparing for disaster mitigation efforts.

In communication studies, human efforts in understanding disasters are included in the concept and study of environmental communication. Flor and Flor (2015) argue that environmental communication is a form of applying a communication approach, both in principle, strategy, technique, and environmental management and protection. Environmental communication is defined as a form of exchange of environmental information, knowledge, and wisdom, leading to mutual understanding between various interested parties. In this effort, a cultural approach and local wisdom can be an effort to preserve the environment.

Based on data from BMKG (Tempo, 2018), Madura Island is included in an earthquake-prone area. BMKG recorded three facts about the earthquake vulnerability on Madura Island after the earthquake hit Sumenep on Wednesday, 13 June 2018. The discovery proves that Madura is not a safe area from earthquakes, as many residents believed so far. According to the BMKG's Head of Earthquake Information and Tsunami Early Warning, there are three facts about the Madura area related to earthquakes. First, tectonically, Madura Island is an earthquake-prone area because of its position in the RMKS fault line zone (Rembang, Madura, Kangen, and Sakala). Second, the evidence of seismic activity in the Madura region shows clusters of shallow seismic activity associated with fault activity. Third, there is a history of earthquake records in Madura. On 20 February 2017, an earthquake in Sampang with a magnitude of 3.7 Richter scale has rocked the western areas of Madura, such as Sampang, Torjun, Ragung, Kedungdung, Karangtengah, Blega, and Konang on the MMI III intensity scale. Also, the Sumenep earthquake occurred on Wednesday night, 13 June 2018, with a magnitude of 4.8 on the Richter Scale.

Speaking of the potential disasters that might occur in several other areas of Madura Island are floods and tornadoes. The potential for earthquakes and other disasters should be addressed wisely by all parties. The Madurese community has a variety of local wisdom that can be maximized as an effort to prevent and mitigate disasters. Madura, with all the distinctive characteristics of its people, has local wisdom that can be maximized in increasing knowledge and understanding of disaster mitigation. The utilization of Madurese local wisdom will be studied further through this research to develop a disaster mitigation system based on Madurese local wisdom.

Several studies on local wisdom and natural disasters have been conducted, including Wikantiyoso (2010), that focuses on spatial planning as one of the efforts and forms of attention to disaster mitigation. According to Wikantiyoso (2010), urban planning and design stakeholders should pay more attention to this issue. The "creation" of a conducive urban environmental situation (planning 
and design for safe cities) should not only formulate "beautiful" plans and designs but should also anticipate the effects of disasters through the mitigation planning process, especially in urban areas located in a disaster-prone zone.

Wardyaningrum (2019) researched the relationships in centralized communication networks for Disaster Risk Reduction. This study aims to obtain results regarding the portrait of the relationship in the community communication network in the Mount Merapi disaster area in Central Java. This research focuses on the process of identifying the centrality of the community communication network around the disaster-prone areas of Dusun Kali Tengah Kidul. The study found that residents were decentralized and spread to many local and outside actors in the communication network regarding disaster evacuation training activities in the Kali Tengah Kidul hamlet. Local actors are usually individuals who have a position in the social structure in the hamlet, while actors from outside the hamlet are usually parties from government agencies or volunteers from higher education institutions. The contents of the message in the disaster evacuation exercise include information about who should be contacted during a disaster, priorities in the evacuation process, evacuation locations and routes, and accommodation. According to Wardyaningrum (2014), the existence of relationships in a centralized communication network between many actors in this region greatly reduces disaster risk with local capacities.

The role of environmental communication in disaster prevention efforts was also discussed by Bakti et al. (2017) regarding environmental communication based on local wisdom as an effort to prevent flooding of the Ciliwung River. The research revealed that the community's local wisdom is utilized by environmental activists around the Citarum Watershed (DAS) to increase environmental awareness and prevent flooding of the Citarum River. Local wisdom was demonstrated in the form of proverbs, rituals, and environmental preservation. The application of environmental communication activities with local wisdom based on Citarum is carried out through personal approaches to several social and religious figures. It is realized through communication platform such as dialogues in farmer group forums, majelis ta'lim (study group), and community empowerment.

Furthermore, Suhardjo (2015) studied disaster mitigation education, focusing on the role of education to reduce disaster risk. In Suhardjo's view, earthquakes and volcanic eruptions are natural disasters that cannot be prevented from the source (Suhardjo, 2015). For this type of disaster, what can be done is Disaster Risk Reduction (PRB). These efforts to reduce risk are disaster mitigation measures.

One of the studies on local wisdom in disaster management was discussed by Raharja et al. (2016) about the community facing landslide natural disasters. Their research in the Bojongkoneng Bogor Village area found that local wisdom of the people of Bojongkoneng Bogor Village was found as a form of landslide disaster mitigation. The forms of its local wisdom include building houses on stilts and pamali or taboo things to do. These pamali/taboo are related to things or actions that damage the environment. There is also local wisdom in the form of knowledge and predictions regarding landslide events that have been passed down from generation to generation.

From the previous research studies, nevertheless, there has been no discussion or research on flood disaster mitigation and Madurese local wisdom. Previous studies have focused more on the role of urban spatial planning in reducing disaster risk. There is indeed research that focuses more on the role of education in reducing disaster risk as a form of disaster mitigation. However, communicationbased research utilizing Madurese local wisdom for disaster mitigation has never been carried out. This is an important point in this research. Efforts to utilize Madurese local wisdom will contribute to disaster mitigation.

\section{METHOD}

This research uses a qualitative design that aims to explain the phenomenon of data collection in detail (Creswell, 2007). The approach in this research is inductive descriptive qualitative thinking, which comes from facts and data in the field that are analyzed and studied with theoretical approaches and thoughts to form new concepts (Neumann, 2007). Descriptive research examines problems in society, procedures in society, and certain situations in a phenomenon. This is intended to provide a complete picture and view of the subject and object of research (Neumann, 2007). Qualitative research intends to interpret a social phenomenon. This study uses the grounded research and action research strategy. The determination of the research strategy is adjusted to the objectives to be obtained in the research, namely to build a communication design (strategy). This research started 
from actual experiences which are then formulated into general models, principles, propositions, and theories (Mulyana, 2005). The research data were obtained through observation, structured interviews, and documentation. The analysis of research data was carried out utilizing processing techniques and procedures as follows: (1) Data sorting and classification; (2) Data editing and coding. Coding means giving codes to data to shape data analysis performance; (3) Data confirmation for the data requiring verification and deepening; and (4) Data analysis based on the structure or construction of the research result discussion.

\section{RESULT AND DISCUSSION}

\section{History of Floods in Sampang.}

Based on its topographical conditions, the Sampang Regency area is made up of a stretch of hills at an altitude of 0-30 m asl, with an average slope of 2-25\%. Topographical conditions like this allow the soil erosion process to occur. This soil erosion process will carry the upper sediments, which will also be carried and deposited in river streams. The sedimentation conditions in the river flow have resulted in silting the river so that it reduces the holding capacity of water, especially when rains come with high intensity and cause flooding. Apart from topographical factors, floods in Sampang are also caused by environmental conditions that do not support water hydrology above the earth's surface. Both of these factors have contributed to the occurrence of flooding in the Sampang area. Most of the forest area is also logged without selective logging; the theft of forest wood has also resulted in the forest land being deforested. This condition resulted in the emergence of critical land and accelerated erosion (BLH, 2010).

The flood incident due to the overflowing of the Kali Kemuning river in Sampang is considered to be very detrimental to the local population, especially if the flood occurs in the Sampang urban area. Various community activities were hampered by flooding. Based on the records, the flood occurred in May 2011 when the water started to overflow on 4 May until it receded on 6 May. The flood inundated five rural areas in the Sampang sub-district of the city. As a result, residents' activities were disrupted, including educational activities, which had to be closed because the schools were flooded. Likewise, office activities have been disrupted because many employees whose houses are flooded have to evacuate their belongings and cannot go to work in the office. At that time, the flood was 50$150 \mathrm{~cm}$ high and greatly affected the flow of transportation between sub-districts in Sampang. The cut-off of the Sampang-Omben road also cut off the flow of transportation between regencies in Madura because of the inundation of the main road axis from Bangkalan to Pamekasan, and vice versa (Priyambodo, 2011).

Based on data from BPBD, floods that occur in Sampang have increased from year to year due to the high intensity of rain. This made the area affected by the flood also expanded. Flood-affected areas in Sampang are not only in the routinely affected areas but have expanded even to some previously unaffected areas. The flood had even taken casualties. The earlier flood usually hit eight villages, yet it hit 13 villages/sub-districts recently. Based on the records, in 2016 until October, the floods hit the same area, namely Kamoning Village, Tanggumung Village, Pasean Village, Panggung Village, Gunung Maddah Dalpenang Village, Rongtengah Village, Rongtengah Village, Karangdalam Village, and Polagan Village. Among these areas, the highest water levels are in Gunung Maddah Village and Kelurahan Dalpenang (Surabaya, 2006).

The data regarding the floods in Sampang was also supported with the statement of Mohammad Imam, Head of Emergency and Logistics of BPBD Sampang, who stated that floods that occur in the city of Sampang area are more often due to floods sent from the northern area of Sampang.

The point is, if the sub-district in North Sampang rains for 4 hours or more, then it is certain that the city Sampang will be flooded. The northern areas are the districts of Robatal, Omben, Karangpenang, and Tambelang” (Interview with Mohammad Imam, 13 August 2020) 


\section{Topographical Conditions in Sampang}

Sampang Regency is located in the eastern part of Madura Island with an average elevation almost the same as the high tide $(+0.3)$. Based on topographical conditions, the Sampang Regency area has various slopes: 0 to $2 \%, 2 \%$ to $15 \%, 15 \%$ to $25 \%, 25 \%$ to $40 \%$, and higher than $40 \%$. Meanwhile, the soil typology in the Sampang area consists of alluvial, grumusol, mediteran, and lithosol soils (Bappeda Sampang, 2010). The river in Sampang is a seasonal river that is full during the rainy season. Residents use this seasonal river water for their paddy fields in the river basin in Sampang. The watershed in Sampang has a flow ranging from 0.7 to $22 \mathrm{~km}$, with the Sodung river as the longest river and the Kalah river as the shortest $0.7 \mathrm{~km}$. The river flow pattern is categorized as a parallel river flow pattern (brainded), winding broken (Anastromic), and permanent, temporary, and periodic chicken claw pattern (Sanitasi, 2013).

\section{Disaster Mitigation}

Mitigation is defined as all forms of continuous action taken to reduce or eliminate long-term property and human life risks. With this definition, mitigation can be interpreted as a mechanism that aims to enable the community to avoid the impact of disasters that may occur. The actions can avoid disaster by not placing people and valuable properties in the disaster area. This is the efforts to control hazards through several developments with special facilities and certain technological applications (Wijanarko, 2006).

Based on the provisions of Article 1 of Law of the Republic of Indonesia Number 24 of 2007 on Disaster Management, disaster mitigation is a series of efforts to reduce disaster risk through physical and awareness development and increased capacity to face disaster threats. Meanwhile, based on Article 1 paragraph 6 of Government Regulation No. 21 of 2008 on the Implementation of Disaster Management, disaster mitigation is a series of efforts to reduce disaster risk through physical and awareness development and increased capacity to face disaster threats. This shows that, in general, mitigation is an effort to reduce and/or eliminate the numbers of victims and losses that may arise. So, the focus of disaster mitigation is at the pre-disaster stage.

There are several disaster mitigation activities, including (1) disaster risk recognition and monitoring activities; (2) participatory disaster management planning activities; establishment of a culture of disaster awareness; (3) application of physical and non-physical efforts, as well as disaster management arrangements; (4) process of identification and recognition of sources of danger or threat of disaster; (5) monitoring of natural resources; (6) monitoring the use of high technology; (7) spatial planning and environmental management activities, as well as other disaster mitigation activities.

According to Kusumasari et al. (2010), there is a critical period when a disaster occurs, and that the leadership is tested. The critical period requires the ability to make the decision correctly, quickly, and with the lowest possible risk. The response process starts immediately after a disaster occurs, and this period does require more complex actions than those for the mitigation, preparedness, and recovery phases.

In the context of flood disaster mitigation in Sampang, the efforts made by the Sampang BPBD are technical and social. According to the observations and interviews with BPBD Sampang, technical efforts are in the form of physical development to revitalize the Kemuning river, installing suction pipes to reduce the risk of flooding in the Sampang area. Meanwhile, socialization efforts are held regularly to the public regarding flood disasters, including flood handling during the incident, such as building a public kitchen, establishing a TRC (Quick Reaction Team), and cross-sectoral cooperation with the Social Service.

We are making routine efforts in tackling the Sampang flood both technical and socialization to the community. The technical ones are in the form of normalization of the function of the Kemuning river, installation of suction pipes" (interview with Mohammad Imam, 13 August 2020)

We also coordinate with the Office of Social Affairs and other related parties when dealing with this flood problem, such as TRC (Quick Reaction Team), construction of public kitchens" (interview with Mohammad Imam, 13 August 2020) 


\section{Local Wisdom}

Anthropologists like Chamber (1987), Ali (2000), and Blaikie (1996) share a similar opinion that each community has its own knowledge to make interpretations of the elements of the natural environment and to manage it to become their life sources. The terminology used for this activity varies, such as local knowledge, indigenous knowledge (Sillitoe, 1998), local wisdom (Mattulada, 1991), traditional wisdom (Norman Edwin, 1991), and traditional knowledge (Samsoedin, 2001). However, whatever term is used, this public knowledge is developed through experience (experimental learning) about a reality. The process of its formation occurs through observation and testing over a long time. This resulted in its development which was not as fast as the development of modern knowledge and technology. Local wisdom in terms of foreign languages is often conceptualized as local wisdom, local knowledge which is a form of work of intellect, character, deep feelings, forms of attitudes / temperament, and suggestions for human dignity (Wagiran, 2012). Traditional wisdom is any form of knowledge, belief, understanding and insight into customs, ethics that guide human behavior in life in their ecological community.

In Keraf's view, people's local wisdom is not only related to people's knowledge and understanding of humans and good relations between humans but also includes knowledge, understanding, customs regarding humans, nature, and the unseen. All the local wisdom is understood, lived, applied, taught, and passed on between generations (Keraf, 2002). Local wisdom is an epistemological conceptual idea in society, growing simultaneously in people's consciousness. Local wisdom functions to regulate people's lives, from those related with scared aspects to profane ones.

\section{Environmental Communication}

Environmental communication in the disaster zone cannot be separated from the knowledge and attitudes of the community regarding various matters related to environmental disasters, including the aspects of physical environmental disasters or the community and the government (As'ari Dan \& Hendriawan, 2016). In an article entitled Environmental Communication and Public Sphere, Pezzullo and Cox define environmental communication as a constitutive and pragmatic means of understanding humans with their environment and humans with nature. Environmental communication is a symbolic medium used to construct environmental problems and negotiate different responses in society (Pezzullo \& Cox, 2018).

According to Pezzullo and Cox, environmental communication comprises two main functions: pragmatic and constitutive. Pragmatically, the concept of environmental communication intersects with education, vigilance, and mobilization practices and helps humans deal with environmental problems. Whereas, in constitutive understanding, environmental communication includes aspects of regulation, arrangement, representation of nature, and environmental problems as the subject of human understanding. Based on this understanding, environmental communication will understand that nature such as forests and rivers are not a threat but as a friend so that humans respect natural resources. With this understanding, humans take advantage of nature through exploitation and the main life support systems and become good environmental friends (Pezzullo \& Cox, 2018).

\section{Variety of Madurese Local Wisdom as Disaster Mitigation Efforts}

The local knowledge system sees humans as a microcosm, with nature as a macrocosm having a harmonious relationship based on the perspective of diversity or heterogeneity. Thus, the local knowledge system not only recognizes a single band but also recognizes the existence of a relative and contextual truth. Truth will only be obtained through a holistic approach and respecting diversity. In the context of the relationship between humans and nature, a functional relationship is found. However, it is not found in the sense of exploitation but rather in the harmoniously established use between humans and nature. Thus, to maintain a relationship with nature, humans must learn continuously through observation and trials in the use of economic resources in their environment.

Local knowledge generally contains environmental wisdom (ecological wisdom) (Vayda, 1981), which allows the formation of an ecosystem balance. Budi Santoso also shares a similar view by saying that Indonesia's plural society is rich in environmental wisdom, which in everyday life is becoming a reference in building sustainable relationships with the environment (Santoso, 1988). A similar opinion was also expressed by Sani and Hijjang, who explained the fact that usually, local people in a certain area have a high form of local wisdom regarding their environment (Hijjang, nd). 
Meanwhile, the concept of indigenous knowledge states knowledge as a cross-disciplinary definition which includes the thinking of local/indigenous people and their way of managing and regulating the environment as a holistic system (Sillitoe, 1998). Indigenous knowledge is an important component in the culture of indigenous people, which forms their cultural system. Their culture includes objects of ceremonial rituals, artistic designs, songs, dances, oral traditions, patterns of subsistence, arrangement of sources of income, and land in certain environments. This knowledge is crucial in ensuring the survival of indigenous cultures and is an important medium for the society to adapt to modern changes that enter their communities (Erlinda Montillo-Burton, 2002).

Traditional knowledge is an important asset in a community-based disaster management system, especially in the disaster mitigation phase. Traditional knowledge and intelligence are formed from the long-term interaction between people and their physical environment. The formation of this traditional intelligence enables the community to know and read natural signals about events before the flood disaster in Sampang, Madura. Because people's understanding of their environment is quite good, disaster management regarding the characteristics of the community's interaction with the local environment can be more effective.

In connection with these objectives, existing traditional knowledge and intelligence need to be extracted and conveyed for future generations to understand. Apart from being applicable in a disaster management system, in the socio-cultural context, traditional knowledge and intelligence are assets that need to be preserved. Traditional knowledge and intelligence show the existence of a social and cultural system in Indonesia that is closely related to the environment and provides specific characteristics.

The expertise of the Sampang Madura community in reading natural signs is shown in the annual flood phenomenon in this city. If there are clouds in the northern Sampang area, it is certain that there will be rain in the area, and there will be flooding in their area. This was confirmed by the following informants:

If the north of Sampang is already cloudy and has some rain, we who are here (Sampang city) are getting ready to face the flood. The reference must be from the north. If there is news from there, definitely we should get ready here. In the north, there is usually a lot of rain (interview with Ikrar Fardino P, a resident of Gunung Madah Village, 23 August 2020)

It can be seen from how long it has been rainy and cloudy, the black color has indicated that there will be floods, so I have prepared here what to protect and dry food that must be available during the flood". (interview with Ila, a resident of Jalan Suhada Sampang, 23 August 2020).

The Madurese kinship system is very strong. Madurese kinship is widely known and open. The term relative in the Madurese context is known as beleh (karabet), taretan dibi. The Madurese people really maintain this kinship relationship so that the culture of visiting each other between relatives is still maintained today. In the context of this flood disaster, the people of Sampang Madura rely heavily on information from their relatives who come from the northern region of Madura to make preparations when a disaster occurs.

I always get news from relatives in the north, especially when it is raining there, and it looks cloudy from here (Sampang city), our relatives in the north will certainly tell us to get ready" (interview with Sulihah, a resident of Kel. GunungMadah, 23 August 2020).

Information from the taretan is very reliable in the process of anticipating floods in the Sampang Madura area. Taretan terminology in Madurese culture is not only limited to siblings or nuclear families but is much broader than that. This is evidenced by the existence of the terms sapopoh taretan, dupopoh taretan, tellopopoh taretan. Even with someone who is still related by blood, even though it is very far related, it is "obligatory" to help each other, guard against disgrace, and defend. This proves that the concept of brotherhood and solidarity in Madurese society is solid (gemenschaft).

The concept of guyub is evident with the use of the terms bung-sabung rosok, songosong lombung, rampa 'naong banyan korong. These terms describe a strong kinship system in Madurese society. The expression bung-sabung rosok literally means the ribs that are joined. This expression shows that kinship relations are highly regarded in the social traditions of the Madurese community. The expression song osong lombung literally means together or work together in lifting the barn. The barn in the context of the Madurese community is used as a storage area for food stocks, that is, corn and rice. This concept reinforces the view of solidarity and the spirit of mutual assistance to the Madurese. In the context of disaster, this expression is very relevant to be applied at the time of flood. 
The expression rampa 'naong banyan korong means the need for a tradition of gathering with fellow families (apol kompol sataretanan).

In the context of disaster, there is also a Madurese expression that is very relevant to human values and empathy, namely "Mellak matana gerreng". This expression is used to warn someone, to help anyone who needs help, and to not act as if not seeing nor pretending not knowing. This expression shows that the Madurese community has a high social sensitivity. The phrase "Nanem cabbi molong cabbi" is also full of societal values and justice. This expression means whoever sows his seed will reap the rewards. This shows the moral value regarding the reward for every action. Good deeds will be rewarded in the form of sympathy and respect, vice versa.

The local Madurese wisdom regarding the spirit of mutual cooperation, togetherness, and mutual assistance is manifested when there is heavy rain in the northern region. The people in Sampang city have received this information from their relatives to prepare themselves for the possibility of a flood disaster. This is a form of concern and spirit of togetherness and solidarity with the local community. This was expressed by Mahsus, one of the residents in the Dalpenang Village.

When a disaster occurs, the community has begun to understand the coordination lines with regional and city organizations. When there will be a flood, the northern community in the yellow area provides information that there is rain with a certain intensity that will have the potential for flooding and they would tell us the areas that are prone to flooding" (interview with Mahsus, resident of Kel. Dalpenang, 25 August 2020).

Furthermore, Madurese local wisdom related to respect and obedience to teachers, parents, and leaders is "Buppa 'bebu' guru rato". This expression is often used by the Madurese community to emphasize respect for parents, teachers, and leaders. In the context of this flood disaster, the people of Sampang Madura strongly believe in the role of prayer and Islamic scholars in dealing with floods. At the beginning of the rainy season, in several areas of Sampang, the ritual of praying together and "rosulan" is still carried out as an expression of gratitude for the arrival of the rainy season. In the view of the people of Sampang Madura, rain is a gift and God's blessing to be grateful for. This ritual is also an expression of prayer for safety during the rainy season. This is like the narrative of the following Sampang residents:

Every time the first rain occurs in the rainy season, the community and I hold a thanksgiving (rasol) at the nearby grave (bhujuk) to pray together for blessings and safety, by bringing food to eat with all the people" (interview with Sumiatun, resident of Sampang kota, 23 August 2020)

By holding thanksgiving and prayer together, asking for safety, protection from harm, because I believe in the prayers of the scholars." (interview with Cholifah, resident of Penggung Sampang, 23 August 2020)

Another form of local wisdom is that the Sampang Madura community built their houses which are specifically designed to reduce the impact of disasters. They, in fact, can survive at home without having to evacuate or leave their homes. The community designed the roof of the house as a place to live temporarily during the flood. This was expressed by Ila, a resident of Jalan Suhada Sampang, as follows:

The community has changed the design of their houses without any mitigation from the government regarding disasters. The community has designed the roof of the house as a place to live during the flood. Items such as stoves and staples have provided staple food that does not spoil easily for their needs during the flood. The government would only provide aid if the floodwater starts to recede. Yes, maybe the government is afraid of being dragged down by a fairly heavy flow of floodwater (interview with Ila, a resident of Jalan Suhada Sampang, 23 August 2020).

\section{Mitigation and Adaptation in the Sampang Flood}

Mitigation and adaptation carried out by the Sampang Madura community are purposed to reduce the calamities due to flooding. Mitigation is all efforts made to anticipate or reduce the impact of a disaster that will occur. However, the effective efforts that could be made before the disaster occurs have not been completed correctly. This action is actually critical to minimize the number of victims in disaster-prone areas. The mitigation paradigm in disaster management is intended to introduce disaster mitigation in prone areas and prepare independent and independent communities. In addition, 
mitigation is also defined as an effort to increase the capacity of people living in disaster-prone areas to anticipate or reduce the level of disaster impact.

Among the types of mitigation that can be done are changing the behavior of an unstable community through settlement planning, building needs, building structures adaptive to flood disaster conditions, and spatial planning with a disaster impact mitigation perspective. Furthermore, awareness of the impact of disasters must be developed and realized in the community. Therefore, it is hoped that the community will not only be the target of support but also be a helper for themselves and the community during disaster conditions. Public awareness is a form of social awareness, including early notification systems, disaster anticipation, disaster response, and post-disaster management capabilities. This type of awareness is one of the social capitals for developing the mitigation stage in every individual in society.

\section{CONCLUSION}

The people of Sampang Madura carried out disaster mitigation based on local wisdom. The wisdom was created based on the local conditions they have experienced so far. The people are always looking for the best way to carry out the local wisdom and adapt to the conditions, as they do over time from one generation to the next ones. Community habits are transformed into local wisdom. Different wisdom is shaped for different locations experiencing different natural problems. This disaster, speaking of local experience, has made the community an independent society. The local wisdom of the Sampang Madura community in dealing with the flood is divided into two parts. The first is their knowledge in recognizing (predicting) a disaster that will occur, such as seeing the natural conditions when it is cloudy in the northern region of Sampang, such as Robatal, Omben, Ketapang, Karangpenang. The second is their actions on disasters, such as relying on information from their relatives in the northern region of Sampang about the flood. The local wisdom is also related to traditional Madurese expressions of kinship, mutual cooperation, and solidarity. All of these components further strengthen the people's bonds and knowledge of the flood disaster they are facing. Apart from all kinds of local wisdom that they have, the spirit of the ancestors is getting stronger, as it is their principle that they will always respect and honor their parents, teachers, scholars, and leaders. The result and findings of this research are expected to contribute to the knowledge and sciences in communication studies, especially environmental and intercultural communication.

\section{REFERENCES}

As'ari Dan, R., \& Hendriawan, N. (2016). Kajian Nilai Kearifan Lokal Masyarakat Adat Kampung Naga Dalam Pengelolaan Lingkungan Berbasis Mitigasi Bencana. Prosiding Seminar Nasional Geografi UMS, 472-486.

Bakti, I., Hafiar, H., \& Budiana, H. R. (2017). Environmental Communication Based on Local Wisdom in Anticipation of Citarum Flood. MIMBAR, Jurnal Sosial dan Pembangunan, 33(1), 208. https://doi.org/10.29313/mimbar.v33i1.2281

Bappeda Sampang. (2010). No Title.

Blaikie, et. al. (1996). Understanding Local Knowledge and the Dynamics of Technical Change in Developing Countries.

BLH, B. L. H. (2010). Kajian Lingkungan Hidup Strategis Tahun 2010.

Chamber, R. (1987). Pembangunan Desa Mulai dari Belakang: LP3ES Jakarta.

Creswell, J. W. (2007). Qualitative enquiry \& research design, choosing among five approaches. In Book: Vol. 2nd ed. https://doi.org/10.1016/j.aenj.2008.02.005

Erlinda Montillo-Burton. (2002). Revival and Enhancement of Indigenous Knowledge Adaptive Collaborative Management: A Philippine Case. Simposium Internasional Ketiga Jurnal Antropologi Indonesia: Membangun Kembali Indonesia yang Bhineka Tunggal Ika: Menuju Masyarakat Multikultural, kerjasama dengan Jurusan Antropologi Fakultas Sastra UNUD.

Flor, A. G., \& Flor, A. G. (2015). Environmental Communication: Principles, Approaches and Strategies of Communication Applied to Environmental Management by (Nomor January 2004).

Hijjang, S. dan. (n.d.). Di antara Kearifan dan Kerawanan Ekologi.

Keraf, A. S. (2002). Etika Lingkungan (. Penerbit Buku Kompas. 
Kompas. (2018). Kompas.com 19/10/2018.

Kusumasari, Bevaola, Q. A. and K. S. (2010). Resource Capability For Local Government in Managing Disaster. Disaster Prevention and Management. Australia. Departement of Management. Faculty of Business and Economics. Monash University, Vol. 19(No 4).

Mattulada. (1991). Sirik dalam Pembinaan Kebudayaan. Majalah Antropologi Sosial dan Budaya Indonesia.

Mulyana, D. (2005). Metode Penelitian Kualitatif, Paradigma baru ilmu komunikasi dan ilmu sosial lainnya. Rosda Karya.

Neumann, L. W. (2007). Basic of Social Science Research, Qualitative and Quantitative Approaches, second Edition. Pearson Education, Inc.

Norman Edwin. (1991). Memahami Kearifan Tradisional Perahu Pinisi',. Kompas, 26 Desember 1991.

Pezzullo, Phaedra C., R. C. (2018). Environmental Communication and the Public Sphere. https://www.m-

culture.go.th/mculture_th/download/king9/Glossary_about_HM_King_Bhumibol_Adulyadej's_ Funeral.pdf

Priyambodo. (2011). Banjir Putuskan Hubungan Dua Kecamatan Madura.

Raharja, R., Grahadi, F. G., Ningsih, R. V, \& Machdum, S. V. (2016). Peran kearifan lokal dalam mitigasi bencana: studi masyarakat dalam menghadapi bencana longsor di desa bojongkoneng, kabupaten Bogor. Journal Dialog Penanggulangan Bencana, 7(2), 103-110.

Saleh M Ali. (2000). Pengetahuan Lokal dan Pembangunan Pertanian Berkelanjutan : Perspektif dari Kaum Marjinal. Jurnal Antropologi Indonesia.

Samsoedin., M. S. and I. (2001). "Traditional Knowledge and Practice of Biodiversity Conservation. In People Managing Forests: The Links Between Human Well-being and Sustainability, (hal. 116-134).

Sanitasi, B. P. (2013). Buku Putih Sanitasi Kabupaten Sampang.

Santoso, B. (1988). “Aktualisasi Nilai-Nilai Tradisional dalam Pelestarian Lingkungan”.

Sartini. (2004). Menggali Kearifan Lokal Nusantara Sebuah Kajian Filsafati. Jurnal Filsafat, Jilid $37(2), 113$.

Sillitoe, P. (1998). “The Development of Indigenous Knowledge.” Current Anthropology, Vol. 39, No. 2. (April, 1998), 223-247.

Suhardjo, D. (2015). Arti Penting Pendidikan Mitigasi Bencana Dalam Mengurangi Resiko Bencana. Jurnal Cakrawala Pendidikan, 2, 174-188. https://doi.org/10.21831/cp.v0i2.4226

Surabaya, S. (2006). Kembali-Alami-Banjir,-8- Kawasan-di-Sampang-Tergenang. http://m.suarasurabaya.net/app/kelanakota/detail/2016/179260-Kembali-Alami-Banjir,-8Kawasan-di-Sampang-Tergenang

Tempo. (2018). Tempo.com 15 Juni 2018.

Vayda, A. (1981). Research in East Kalimantan on Interaction Between People and Forest: A Preliminary Report.

Wagiran, D. (2012). Pengembangan Model Pendidikan Kearifan Lokal di Wilayah Provinsi DIY dalam Mendukung Perwujudan Visi Pembangunan DIY menuju Tahun 2020 (Tahun Kedua).

Wardyaningrum, D. (2014). Perubahan Komunikasi Masyarakat Dalam Inovasi Mitigasi Bencana di Wilayah Rawan Bencana Gunung Merapi. Jurnal ASPIKOM, 2(3), 179. https://doi.org/10.24329/aspikom.v2i3.69

Wardyaningrum, D. (2019). Relations in the Communication Networks Centrality for Disaster Risk Reduction. Komunikator, 11(1). https://doi.org/10.18196/jkm.111016

Wijanarko, H. (2006). Disaster Management di Negeri Rawan Bencana. The Jakarta Consulting Grup.

Wikantiyoso, R. (2010). Mitigasi Bencana Di Perkotaan; Adaptasi Atau Antisipasi Perencanaan Dan Perancangan Kota? (Potensi Kearifan Lokal Dalam Perencanaan Dan Perancangan Kota Untuk Upaya Mitigasi Bencana). Local Wisdom, Volume:II (MITIGASI BENCANA), 1829. http://www.respati.ucoz.com 